\title{
ANALISIS PENGARUH ASPEK HUKUM, PERAN BIDAN DAN HAK ANAK TERHADAP PRAKTIK PEMBERIAN ASI EKSKLUSIF DI KABUPATEN KLATEN
}

\author{
Sumantri, Gita Kostania \\ Kementerian Kesehatan Politeknik Kesehatan Surakarta Jurusan Kebidanan
}

\begin{abstract}
Legal Aspects, The Role Of Midwife, The Rights Of Children, Exclusive Breastfeeding. The purpose of this study is to analyze the influence of the legal aspects, the role of the midwife and the right of children on exclusive breastfeeding practice. This type of research is analytical study with cross-sectional research design. An estimated 1,000 Mothers with infants aged 0-12 months in the Klaten district with 30\% of the sample population, it's about 300 people. The sampling technique used cluster random sampling. Analysis of the data used by the statistical test Chi-Square and logistic regression. Results: 1) legal aspect of regulation Exclusive Breastfeeding is significantly affect the exclusive breastfeeding practice, $p 0.000(P<0.05) ; X 2: 23.5$; RP: 1.80 and $95 \%$ CI: $1: 40$ to $2: 31 ; 2)$ the role of the midwife in exclusive breastfeeding practice showed a significant effect, $p 0.001$ ( $P<0.05)$; X2: 11.9; RP: 1:52 and 95\% CI: 1.22-1.89, and; 3 ) the right of the child to exclusive breastfeeding practice showed a significant effect, $p 0.000$ ( $P<0.05)$; X2: 32.3; RP: $2: 07$ and $95 \%$ CI: $1.55-2.66$.
\end{abstract}

Keywords: Legal Aspects, The Role Of Midwife, The Rights Of Children, Exclusive Breastfeeding.

Abstrak: Aspek Hukum, Peran Bidan, Hak Anak, Asi Eksklusif. Penelitian ini bertujuan untuk menganalisis pengaruh aspek hukum, peran bidan dan hak anak terhadap praktik pemberian ASI Eksklusif. Jenis penelitian ini adalah analitik dengan desain penelitian cross sectional. Sejumlah 1000 Ibu yang memiliki bayi usia 0-12 bulan di Kabupaten Klaten sebagai populasi dengan 30\% sampel yaitu 300 orang. Teknik pengambilan sampel yang digunakan acak gugus atau cluster sampling. Analisis data yang digunakan dengan uji statistik Chi-Square dan regresi logistic. Hasil Penelitian: 1) aspek hukum berupa Perda Asi Eksklusif berpengaruh secara signifikan terhadap praktik pemberian ASI Eksklusif, $p 0.000$ ( $p<0.05) ; X^{2}: 23.5$; RP: 1.80 dan CI 95\%: $1.40-2.31$; 2) peran bidan terhadap praktik pemberian ASI eksklusif menunjukkan pengaruh yang signifikan, $p 0.001(p<0.05) ; X^{2}$ : 11.9; RP:1.52 dan CI 95\%: 1.22-1.89, dan; 3) hak anak terhadap praktik pemberian ASI eksklusif menunjukkan pengaruh yang signifikan, $p 0.000(p<0.05) ; X^{2}: 32.3$; RP: 2.07 dan CI 95\%: 1.55-2.66.

Kata Kunci: Aspek Hukum, Peran Bidan, Hak Anak, Asi Eksklusif.

PENDAHULUAN

Angka kematian bayi (AKB) salah satu dari delapan target Millenium sebesar 23/1.000 kelahiran hidup menjadi Development Goals (MDGs) yang mesti 
dicapai hingga tahun 2015. Angka kematian bayi di Indonesia pada tahun 2000 sebesar 34/1.000 kelahiran hidup, angka ini lebih tinggi dibanding dengan negara-negara di Asia Tenggara, seperti Malaysia, Filipina, dan Thailand (Depkes RI, 2008).

Praktek menyusui yang baik sangat penting untuk keberlangsungan partumbuhan, kesehatan dan gizi bayi serta anak-anak. Oleh sebab itu, lamanya pemberian ASI eksklusif merupakan salah satu masalah kesehatan masyarakat yang penting. The Expert Consultation dari WHO merekomen-dasikan pemberian ASI eksklusif selama 6 bulan, diikuti pengenalan makanan tambahan dan tetap melanjutkan ASI setelahnya. Pra-syarat penerapan rekomendasi ini adalah tersedianya dukungan sosial dan gizi memadai untuk wanita menyusui (Walker, 1998).

Praktek pemberian ASI di Indonesia masih memprihatinkan. Berdasarkan data SDKI tahun 2003, bahwa pemberian ASI saja cenderung terus menurun seiring dengan bertambahnya usia bayi. Pemberian ASI saja pada bayi 2-3 bulan sebanyak 45,5\%, pada bayi 4-5 bulan sebanyak $13,9 \%$ dan pada bayi 6-7 bulan hanya 7,8\% Penelitian Hardinsyah dkk (2001) di kota Bogor, menemukan bahwa pemberian ASI ekslusif antara 4 - 5 bulan adalah 23,9\%, sedangkan penelitian yang dilakukan oleh Irawati (2004) di Kecamatan Sukaraja Kabupaten Bogor hanya 2,6 \%.

Pemberian ASI pada bayi erat kaitannya dengan keputusan ibu bayi. Penelitian Hannon et al (1997) di Amerika Serikat pada ibu keluarga miskin menemukan bahwa faktor utama yang mempengaruhi keputusan ibu dalam praktek pemberian ASI, yaitu pengetahuan ibu mengenai manfaat ASI dan cara mengatasi kesulitan menyusui. Hal senada dikemukakan oleh Dermer (2001) bahwa faktor yang mempengaruhi keputusan ibu memberikan ASI adalah paparan informasi tentang manfaat ASI dan cara menyusui. Sedangkan menurut Killewo et al (2002) faktor yang mempengaruhi keputusan pemberian ASI di daerah perdesaan Bangladesh adalah persepsi ibu tentang ASI eksklusif.

Pemberian ASI eksklusif di Indonesia diatur dalam undang-undang kesehatan No.36 tahun 2009 pada pasal 128 ayat (1), (2),(3) dan pasal 129 ayat (1) bahwa setiap bayi harus mendapatkan Air Susu Ibu (ASI) eksklusif selama enam bulan. Berdasarkan Susenas (2010), pemberian ASI eksklusif di Indonesia sebesar 61,5 (BPPN, 2010).

Penelitian ini bertujuan untuk menganalisis pengaruh aspek hukum, peran bidan dan hak anak terhadap praktik pemberian ASI Eksklusif.

\section{METODE PENELITIAN}

Penelitian ini merupakan studi potong lintang. Studi potong lintang ini adalah suatu rancangan penelitian dengan cara mengobservasi variabel bebas (faktor risiko) dengan variabel tergantung (efek) hanya sekali pada saat yang sama (Dahlan, 2006). Adapun aspek hukum, peran bidan dan hak anak merupakan variabel bebas (faktor risiko) dengan variabel tergantung (efek) adalah praktik pemberian ASI Eksklusif. Penelitian dilaksanakan di Kecamatan Wilayah Kabupaten Klaten. Waktu pengambilan data penelitian mulai bulan Juni s/d 16 Agustus 2014. Populasi dalam penelitian ini adalah semua ibu yang memiliki bayi usia 0-12 bulan di Kabupaten Klaten kurang lebih 1000 orang. Cara 
pengambilan sampel dengan cara acak gugus (cluster sampling). Sampel diambil $30 \%$ dari sejumlah ibu yang memiliki bayi usia 0-12 bulan, didapatkan ibu menyusui sebanyak 300 orang.

Pengumpulan data aspek hukum, aspek peran bidan dan aspek hak anak serta praktik pemberian ASI eksklusif dengan cara pembagian angket secara langsung melalui bidan desa bersamaan kegiatan pemeriksaan di Praktek Bidan Mandiri maupun di Posyandu di Wilayah domisili responden. Cara pengisian angket dilakukan secara langsung.

$$
\text { Pengolahan data dengan }
$$
menggunakan sistem komputerisasi STATA. Analisis data dengan analisis univariat, bivariate dan multivariate. Analisis univariat dilakukan untuk mendiskripsikan karakteristik responden dan mendiskripsikan setiap variabel. Analisis bivariat digunakan untuk menganalisis pengaruh masing-masing aspek: hukum, peran bidan dan hak anak terhadap praktik pemberian ASI eksklusif. Analisis yang digunakan adalah dengan uji statistik Chi-Square. Analisis multivariat dilakukan untuk menganalis ke-tiga secara bersama-sama variabel yang paling dominan mempengaruhi praktik pemberian ASI eksklusif. Jenis analisis yang digunakan uji statistik regresi logistic.

\section{HASIL PENELITIAN}

Penelitian dengan membagikan angket diberikan kepada 300 responden yang tersebar pada 26 Kecamatan, 301 Desa dan 10 Kelurahan. Responden dalam penelitian ini adalah ibu-ibu yang memiliki bayi yang berumur kurang dari 1 tahun. Untuk mengetahui latar belakang responden, peneliti mendapatkan data karakteristik responden berdasarkan umur, pendidikan dan pekerjaan. Adapun karakteristik responden tersebut seperti pada tabel berikut:

\section{Tabel 1}

Karakteristik Responden Berdasarkan Umur, Pendidikan dan Pekerjaan

\begin{tabular}{cccc}
\hline No. & $\begin{array}{c}\text { Karakteristik } \\
\text { Responden }\end{array}$ & $\mathrm{f}$ & $\begin{array}{c}\text { Persentase } \\
(\%)\end{array}$ \\
\hline $1 . \quad$ Umur (tahun) & & \\
& $<20$ & 15 & 5.0 \\
& $20-35$ & 261 & 87.0 \\
2. & $>35$ & 24 & 8.0 \\
& Pendidikan & & \\
& SD & 63 & 21.0 \\
SLTP & 99 & 33.0 \\
SLTA & 112 & 37.3 \\
3. & PT & 26 & 8.7 \\
& Pekerjaan & & \\
IRT & 187 & 62.3 \\
& Buruh & 51 & 17.0 \\
& Swasta & 48 & 16.0 \\
PNS & 14 & 4.7 \\
\hline
\end{tabular}

Tabel di atas menunjukkan bahwa karakteristik responden berdasarkan umu dikategorikan menjadi 3 kategori, yaitu kurang dari 20 tahun, 20-35 tahun dan lebih dari 35 tahun. Umur responden sebagian besar berumur 20-35 tahun sebanyak 261 responden (87\%) dan usia kurang dari 20 tahun dan lebih dari 35 tahun sejumlah 39 responden (13\%).

Pendidikan responden dikategorikan dalam SD, SLTP, SLTA dan PT. Tabel di atas menunjukkan sebagian besar responden memiliki pendidikan terakhir SLTA sebanyak 112 responden (37.3\%), SLTP sebanyak 99 responden (33\%), SD sebanyak 63 responden $(21 \%)$ dan PT sebanyak 26 responden $(8.7 \%)$.

Pekerjaan responden dikategorikan menjadi 4 kategori, yaitu IRT, buruh, swasta dan PNS. Tabel di atas menunjukkan bahwa sebagian besar responden ibu rumah tangga (IRT), yaitu sebanyak 187 responden $(62.3 \%)$. 
Sedangkan responden lainnya bekerja sebagai buruh, swasta dan PNS.

Untuk mendapatkan gambaran masing-masing variabel penelitian yang terdiri atas aspek hukum, peran bidan, hak anak dan praktik menyusui secara eksklusif peneliti mengkategorikan masing-masing dalam kategori ya dan tidak. Yang dimaksud dengan kategori ya apabila responden melaksanakan dan tidak apabila responden tidak melaksanakan sesuai dengan kelompok variabel.

Adapun gambaran masing-masing variabel penelitian dapat dilihat pada tabel distribusi frekuensi di bawah ini:

Tabel 2

Distribusi Frekuensi Variabel Penelitian

\begin{tabular}{|c|c|c|c|}
\hline No & Variabel & $\mathrm{F}$ & $\begin{array}{c}\text { Persentase } \\
(\%)\end{array}$ \\
\hline 1. & $\begin{array}{c}\text { Aspek Hukum } \\
\text { Ya } \\
\text { Tidak }\end{array}$ & $\begin{array}{l}1 \\
5 \\
1 \\
1 \\
4 \\
9\end{array}$ & $\begin{array}{l}50.3 \\
49.7\end{array}$ \\
\hline 2 & $\begin{array}{c}\text { Peran Bidan } \\
\text { Ya } \\
\text { Tidak }\end{array}$ & $\begin{array}{l}81 \\
219 \\
\end{array}$ & $\begin{array}{l}27.0 \\
73.0\end{array}$ \\
\hline 3. & $\begin{array}{c}\text { Hak Anak } \\
\text { Ya } \\
\text { Tidak }\end{array}$ & $\begin{array}{l}158 \\
142\end{array}$ & $\begin{array}{l}52.7 \\
47.3\end{array}$ \\
\hline 4. & $\begin{array}{l}\text { Praktik } \\
\text { Pemberian } \\
\text { Asi Eksklusif } \\
\quad \text { Ya } \\
\quad \text { Tidak }\end{array}$ & $\begin{array}{l}147 \\
153\end{array}$ & $\begin{array}{l}49.0 \\
51.0\end{array}$ \\
\hline
\end{tabular}

Tabel di atas menunjukkan bahwa responden melakukan praktik menyusui secara eksklusif kepada bayi-nya karena alasan di Kabupaten Klaten terdapat Perda ASI dari 300 responden lebih dari 50\%, yaitu sebanyak 151 responden (50.3\%). Sedangkan responden pada praktik menyusui secara eksklusif kepada bayinya bukan karena alasan di Kabupaten Klaten terdapat Perda ASI sebanyak 149 responden (49.7\%).

Responden pada praktik menyusui secara eksklusif kepada bayi-nya karena alasan bidan pernah menganjurkan (peran bidan) hanya sebanyak 81 responden $(27 \%)$. Sedangkan responden pada praktik menyusui secara eksklusif kepada bayinya karena alasan bidan tidak pernah menganjurkan (peran bidan) sebanyak 219 responden $(73 \%)$.

Responden pada praktik menyusui secara eksklusif kepada bayi-nya karena alasan pemenuhan hak anak sebanyak 158 responden $(52.7 \%)$. Sedangkan responden pada praktik menyusui secara eksklusif kepada bayi-nya karena alasan bukan merupakan hak anak sebanyak 142 responden (47.3\%).

Tabel di atas menunjukkan bahwa dari 300 responden yang mempraktikkan pemberian ASI Eksklusif kepada bayi-nya sebanyak 147 responden (49\%) dan sebanyak 153 responden (51\%) tidak mempraktikkan pemberian ASI Eksklusif kepada bayi-nya.

Analisis bivariat digunakan untuk menganalisis pengaruh masing-masing variabel bebas terhadap variabel terikat dengan menggunakan uji statistik chisquare. Adapun hasil analisis bivariat seperti pada tabel berikut: 
Tabel 3

Pengaruh Aspek Hukum, Peran Bidan dan Hak Anak Terhadap Praktik Pemberian ASI Eksklusif Dengan Uji Chi-Square

\begin{tabular}{ccccc}
\hline & \multicolumn{3}{c}{ Praktik Pemberian ASI Eksklusif } \\
\cline { 2 - 5 } & \multicolumn{2}{c}{ Ya } & \multicolumn{2}{c}{ Tidak } \\
\cline { 2 - 6 } & $\mathrm{n}$ & $\%$ & $\mathrm{n}$ & $\%$ \\
\hline
\end{tabular}

\begin{tabular}{lrrrr}
\hline Aspek Hukum & & & & \\
Ya & 95 & 62.9 & 56 & 37.1 \\
Tidak & 52 & 34.9 & 97 & 65.1 \\
\hline Peran Bidan & & & & \\
Ya & 53 & 65.4 & 28 & 34.6 \\
Tidak & 94 & 42.9 & 125 & 57.1 \\
Hak Anak & & & & \\
Ya & 102 & 64.6 & 56 & 35.4 \\
Tidak & 45 & 31.7 & 97 & 68.3 \\
$X^{2}$ & $p$ & $R P$ & $C I 95 \%$ & \\
\hline
\end{tabular}

\begin{tabular}{llll}
\hline 23.5 & 0.000 & 1.80 & $\begin{array}{l}1.40- \\
1\end{array}$ \\
& & 2.31 \\
\hline \multirow{2}{*}{11.9} & 0.001 & $\begin{array}{l}1.52 \\
1\end{array}$ & $\begin{array}{l}1.22- \\
1.89\end{array}$ \\
\hline \multirow{2}{*}{32.3} & 0.000 & $\begin{array}{l}2.07 \\
1\end{array}$ & $\begin{array}{l}1.55- \\
2.66\end{array}$ \\
\hline
\end{tabular}

Tabel di atas secara statistik menunjukkan bahwa aspek hukum berupa Perda Asi Eksklusif berpengaruh secara signifikan terhadap praktik pemberian ASI Eksklusif, karena p 0.000 ( $\mathrm{p}<0.05$ ); X2: 23.5; RP: 1.80; dengan CI 95\%: 1.402.31. Adapun pengaruh aspek hukum berupa Perda Asi Eksklusif terhadap praktik pemberian ASI Eksklusif sebesar 1.80, artinya responden yang memiliki bayi umur kurang dari 1 tahun cenderung akan mempraktikkan pemberian ASI secara eksklusif kepada bayi-nya karena responden mengetahui terdapat Perda Asi Eksklusif sebesar 1.80 kali lebih tinggi jika dibandingkan dengan responden yang tidak mengetahui adanya Perda ASI eksklusif.
Pengaruh peran bidan terhadap praktik pemberian ASI eksklusif pada tabel di atas menunjukkan pengaruh yang signifikan, karena p $0.001(\mathrm{p}<0.05) ; \mathrm{X} 2$ : 11.9; RP:1.52 dengan CI 95\%: 1.22-1.89. Besarnya pengaruh peran bidan terhadap praktik pemberian ASI eksklusif adalah 1.52, artinya responden yang memiliki bayi umur kurang dari 1 tahun cenderung akan mempraktikkan pemberian ASI secara eksklusif kepada bayi-nya karena responden pernah mendapatkan anjuran dari bidan untuk memberikan Asi Eksklusif (peran bidan) sebesar $1.52 \mathrm{kali}$ lebih tinggi jika dibandingkan dengan responden yang tidak pernah dianjurkan oleh bidan tentang ASI eksklusif.

Hasil analisis pengaruh hak anak terhadap praktik pemberian ASI eksklusif menunjukkan pengaruh yang signifikan, karena p $0.000(\mathrm{p}<0.05))$; X2: 32.3; RP: 2.07 dengan CI 95\%: 1.55-2.66. Besarnya pengaruh hak anak terhadap praktik pemberian ASI eksklusif adalah 2.07, artinya responden yang memiliki bayi umur kurang dari 1 tahun cenderung akan mempraktikkan pemberian ASI secara eksklusif kepada bayi-nya karena responden beralasan memberikan Asi Eksklusif karena memenuhi hak anak sebesar 2.07 kali lebih tinggi jika dibandingkan dengan responden yang tidak beralasan memberikan ASI Eksklusif karena memenuhi hak anak.

Analisis multivariat dilakukan oleh peneliti untuk menguji pengaruh semua variabel bebas terhadap variabel terikat secara bersamaan. Uji statistik yang digunakan dalam analisis multivariat adalah regresi logistic. Hasil analisis multivariat pada penelitian ini disajikan dalam tabel di bawah ini: 
Tabel 4

Pengaruh Aspek Hukum, Peran Bidan dan Hak Anak Terhadap Praktik Pemberian ASI Eksklusif Dengan Uji Regresi Logistic.

\begin{tabular}{lccc}
\hline $\begin{array}{l}\text { Praktik } \\
\text { Pemberian }\end{array}$ & OR & $p$ & $C I 95 \%$ \\
ASI Eksklusif & & & \\
\hline Aspek Hukum & 2.90 & 0.000 & $1.73-4.87$ \\
Peran Bidan & 2.63 & 0.001 & $1.46-4.72$ \\
Hak Anak & 2.92 & 0.000 & $1.75-4.85$ \\
\hline
\end{tabular}

Berdasarkan analisis multivariat dengan uji statistik regresi logistic pada tabel di atas menunjukkan bahwa aspek hukum, peran bidan dan hak anak berpengaruh secara signifikan dengan $\mathrm{p}<$ 0.05 dan CI $95 \%>1$. Hasil penelitian ini dapat diartikan bahwa: aspek hukum, peran bidan dan hak anak menjadi faktor yang mendorong ibu yang memiliki anak usia $<1$ tahun untuk memberikan ASI-nya kepada bayinya karena OR $>1$.

\section{PEMBAHASAN}

Karakteristik umur responden dalam penelitian ini $87 \%$ berumur $20-35$ tahun. Hasil penelitian ini sesuai dengan penelitian Anggrita (2008), bahwa karakteristik umur ibu yang memberikan ASI eksklusif di Wilayah Puskesmas Medan Amplas adalah berumur 20-35 tahun. Hasil penelitian ini ditegaskan oleh Notoatmodjo (2010), bahwa usia mempengaruhi daya tangkap, pola pikir dan pemahaman seseorang. Semakin bertambah usia sampai usia kurang lebih 20-35 tahun maka akan semakin berkembang daya tangkap dan pola pikirnya sehingga pengetahuan yang diperolehnya semakin membaik. Karakteristik umur responden apabila dihubungkan dengan penelitian ini, bahwa ibu yang berumur 20-35 tahun pengetahuannya produktif dan mudah memahami aspek hukum maupun menerima pengetahuan dari bidan saat memberikan penyuluhan maupun konseling (Notoatmodjo, 2010).

Karakteristik pendidikan responden mayoritas SLTP ke bawah. Apabila dibandingkan dengan hasil penelitian Kiki Anggrita (2008), bahwa ibu yang pendidikannya SLTP ke bawah justru cenderung memberikan ASI-nya sampai usia 6 bulan kepada bayinya. Dalam penelitian Afifah (2007), ibu menyusui yang pendidikannya rendah lebih mau mengikuti anjuran pemerintah dan mau meninggalkan kebiasaan yang dapat membahayakan kesehatan anaknya dalam pemberian ASI eksklusif (Afifah, 2007).

Hasil penelitian ini sesuai dengan rekomendasi dari World Health Organization (WHO), bahwa bayi baru lahir sampai usia 6 bulan hanya diberikan ASI saja (Dep Kes RI, 2005).22 Fikawati Sandra (2010) disebutkan bahwa dalam pasal 128 ayat 2 dan 3 Undang-Undang Republik Indonesia Nomor 36 Tahun 2009 tentang "Kesehatan" disebutkan bahwa selama pemberian ASI fihak keluarga, pemerintah daerah dan masyarakat harus mendukung ibu secara penuh dengan menyediakan waktu dan fasilitas khusus. Penyediaan fasilitas khusus sebagaimana dimaksud pada ayat (2) diadakan di tempat kerja dan tempat sarana umum (Fikawati, 2010).

Peraturan yang mendukung aspek hukum terhadap praktik pemberian ASI eksklusif adalah tertuang pada pasal 12 dan 14 pemberian sanksi kepada pihakpihak yang tidak mendukung suksesnya ASI eksklusif. Dalam pasal 12 dan 14 tentang pemasaran pengganti ASI adalah promosi, peredaran, penjualan dan periklanan produk. Sarana pelayanan kesehatan dilarang digunakan untuk: 
kegiatan promosi susu formula bayi dan susu formula bayi lanjutan, dilarang menyediakan pelayanan dibidang kesehatan atas biaya yang disediakan oleh badan usaha dengan imbalan promosi susu formula, dilarang menerima sampel ataupun sumbangan susu formula bayi dan susu formula lanjutan untuk keperluan rutin atau penelitian (Fikawati, 2010).

Peran awal bidan dalam praktik pemberian ASI eksklusif menurut Program Manajemen Laktasi (2004) adalah meyakinkan bahwa bayi memperoleh makanan yang mencukupi dari payudara ibunya dan membantu ibu sedemikian rupa sehingga ibu mampu menyusui bayinya sendiri. Dijelaskan pula dalam Program Manajemen Laktasi (2004) peran bidan selanjutnya dalam praktik pemberian ASI eksklusif dengan: (1) membiarkan bayi bersama ibunya dengan segera setelah lahir selama beberapa jam pertama, (2) mengajarkan cara merawat payudara yang sehat pada ibu untuk mencegah masalah umum yang timbul, (3) membantu ibu pada waktu pertama kali memberi ASI, (4) menempatkan bayi didekat ibunya pada kamar yang sama (rawat gabung), (5) memberikan ASI pada bayi sesering mungkin, (6) memberikan kolostrum dan ASI saja, dan (7) menghindarkan susu botol dan "dot empeng" (Program manajemen Laktasi, 2004).

Pengaruh hak anak terhadap praktik pemberian ASI eksklusif menunjukkan pengaruh yang signifikan, karena p 0.000 ( $\mathrm{p}<0.05)$ ); X2: 32.3 dengan CI 95\%: 1.55-2.66. Hak bayi mendapatkan ASI diartikan mendapat ASI sesuai dengan resolusi World Health Assembly (WHA) tahun 2001, bahwa bayi mendapat ASI eksklusif sejak lahir sampai usia 6 bulan, selanjutnya diberikan MP-
ASI dan pemberian ASI diteruskan sampai usia 2 tahun atau lebih (IDAI Cabang DKI Jakarta, 2008). Ditegaskan pula oleh IDAI (2008), pengaruh hak anak terhadap praktik pemberian ASI eksklusif ini didukung Undang-Undang Perlindungan Anak Bab I Pasal 1 No 12 dan Bab II Pasal 2, bahwa mendapatkan Air Susu Ibu (ASI) merupakan salah satu hak asasi bayi yang harus dipenuhi sekaligus hak setiap ibu untuk menyusui bayi-nya (IDAI, 2008).

\section{KESIMPULAN DAN SARAN}

Hasil penelitian ini dapat disimpulkan bahwa aspek hukum, peran bidan dan hak anak mempengaruhi praktik pemberian ASI eksklusif, dan hipotesis diterima.

Pemerintah baik negeri maupun swasta dapat mensosialisasikan kepada masyarakat sekitarnya tentang kewajiban memberikan ASI eksklusif bada bayi sebagai bentuk upaya memenuhi hak asasi bayi, minimal selama 6 bulan, dan mengawasi pemasaran susu formula, serta memberikan sanksi pada pengguna susu formula yang tidak tepat sasaran. Sosialisasi dapat dilakukan dengan pemasangan spanduk, leflet pada tempattempat yang dapat dibaca oleh masyarakat. Pemerintah Kabupaten Klaten secara berkala diharapkan mengevaluasi tercapainya ASI eksklusif.

Bidan dapat mengoptimalkan perannya pada saat melakukan perawatan kehamilan, perawatan persalinan dan kunjungan neonatus melalui konseling dan penyuluhan tentang ASI eksklusif. Bidan dapat mendorong tumbuhnya peran serta masyarakat untuk membentuk kelompok peminatan ASI eksklusif (KP-ASI), sehingga menjadi pusat rujukan terbawah bagi masyarakat yang mengalami 
kebingungan ataupun kesulitan praktik pemberian ASI eksklusif.

Bagi calon ibu dan ibu-ibu yang memiliki anak usia 0-24 bulan agar memberikan ASI saja dari lahir sampai usia 6 bulan sebagai makanan tunggal dan dilanjutkan setelah 6 bulan sampai usia 24 bulan dengan didampingi makanan tambahan.

Diharapkan hasil penelitian ini dapat menjadi data dasar untuk pengembangan penelitian sejenis, guna mendukung sukses dan tercapainya praktik pemberian ASI eksklusif di Indonesia.

\section{DAFTAR RUJUKAN}

Afifah, D,N.. (2007). Faktor yang Berperan dalam Kegagalan Praktik Pemberian ASI Eksklusif, Skripsi. Semarang: Fakultas Kedokteran UNDIP.

Fikawati, Sandra. (2010). Kajian Implementasi dan Kebijakan Air Susu Ibu Eksklusif Dan Inisiasi Menyusu Dini di Indonesia, Makara Kesehatan, Jurnal, Vol 14, No 1, Juni 2010; 17-24.
Hardinsyah et. al. (2001). Infant Feeding Practice in Urban Bogor. Departement of Community Nutrition and Family Resources, Bogor Agricultural University in Collaboration with WHO Indonesia. Bogor: Ministry of Health, and National Agency for Drug and Food Control.

Kiki, Anggrita. (2008). Hubungan Karakteristik Ibu Menyusui Terhadap Pemberian ASI Eksklusif Di Wilayah Kerja Puskesmas Medan Amplas, Skripsi, Sumantera Utara: Fakultas Kedokteran, USU.

Killewo et al. (2002). Determinant of Exclusive Breastfeeding in a Rural Area of Bangladesh. Bangladesh: Bangladesh Publisher.

Notoatmodjo, S. (2010). Promosi Kesehatan. Jakarta: Penerbit Rineka Cipta.

Program Manajemen Laktasi. (2004). Buku Bacaan Manajemen Laktasi. Jakarta. 